\title{
Three-dimensional LASIK flap thickness variability: topographic central, paracentral and peripheral assessment, in flaps created by a mechanical microkeratome (M2) and two different femtosecond lasers (FS60 and FS200)
}

This article was published in the following Dove Press journal:

Clinical Ophthalmology

2 April 2013

Number of times this article has been viewed

\section{A John Kanellopoulos 1,2 George Asimellis' \\ 'Laservision.gr Institute, Athens, Greece; ${ }^{2}$ NYU Medical School, New York, USA}

Video abstract

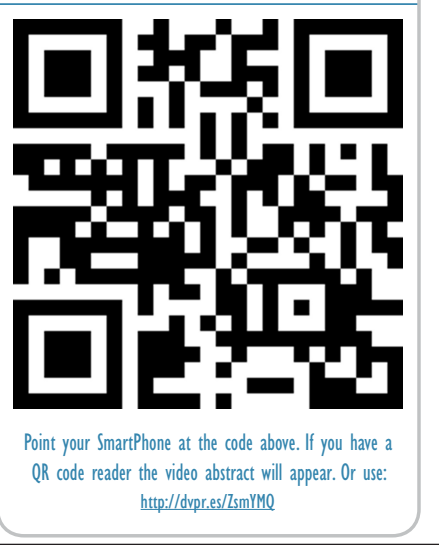

Correspondence: A John Kanellopoulos Laservision.gr Institute,

17 Tsocha Street, Athens,

Greece II52I

Tel +302107472777

Fax +302107472789

Email ajk@brilliantvision.com
Purpose: To evaluate programmed versus achieved laser-assisted in situ keratomileusis (LASIK) flap central thickness and investigate topographic flap thickness variability, as well as the effect of potential epithelial remodeling interference on flap thickness variability.

Patients and methods: Flap thickness was investigated in 110 eyes that had had bilateral myopic LASIK several years ago (average $4.5 \pm 2.7$ years; range 2-7 years). Three age-matched study groups were formed, based on the method of primary flap creation: Group A (flaps made by the Moria Surgical M2 microkeratome [Antony, France]), Group B (flaps made by the Abbott Medical Optics IntraLase ${ }^{\mathrm{TM}}$ FS60 femtosecond laser [Santa Ana, CA, USA]), and Group C (flaps made by the Alcon WaveLight ${ }^{\mathbb{R}}$ FS200 femtosecond laser [Fort Worth, TX, USA]). Whole-cornea topographic maps of flap and epithelial thickness were obtained by scanning high-frequency ultrasound biomicroscopy. On each eye, topographic flap and epithelial thickness variability was computed by the standard deviation of thickness corresponding to 21 equally spaced points over the entire corneal area imaged.

Results: The average central flap thickness for each group was $138.33 \pm 12.38 \mu \mathrm{m}$ (mean \pm standard deviation) in Group A, 128.46 $\pm 5.72 \mu \mathrm{m}$ in Group B, and $122.00 \pm 5.64 \mu \mathrm{m}$ in Group C. Topographic flap thickness variability was $9.73 \pm 4.93 \mu \mathrm{m}$ for Group A, $8.48 \pm 4.23 \mu \mathrm{m}$ for Group B, and $4.84 \pm 1.88 \mu \mathrm{m}$ for Group $\mathrm{C}$. The smaller topographic flap thickness variability of Group C (FS200) was statistically significant compared with that of Group A (M2) $(P=0.004)$, indicating improved topographic flap thickness consistency - that is, improved precision - over the entire flap area affected.

Conclusions: The two femtosecond lasers produced a smaller flap thickness and reduced variability than the mechanical microkeratome. In addition, our study suggests that there may be a significant difference in topographic flap thickness variability between the results achieved by the two femtosecond lasers examined.

Keywords: Moria M2, IntraLase FS60, WaveLight ${ }^{\circledR}$ FS200, Allegretto Wave ${ }^{\circledR}$ Eye-Q, 400 Hz excimer, ultrasound biomicroscopy

\section{Introduction}

We have previously reported, in agreement with many others, on the safety and accuracy of flap making with mechanical keratomes for correction of myopia and myopic astigmatism $^{1}$ as well as hyperopia. ${ }^{2}$ 
The femtosecond laser-named for the ultrashort pulses it produces that last a few femtoseconds (ie, $10^{-15}$ of a second) has provided an alternative option for flap creation since the introduction of the IntraLase ${ }^{\mathrm{TM}}$ (Abbott Medical Optics, Santa Ana, CA, USA) in 2001. ${ }^{3}$ With wavelength around $1050 \mathrm{~nm}$ - at which the cornea tissue is transparent - the laser energy can be tightly focused within the corneal stroma. Typically, each laser pulse consists of very low energy (eg, of the order of $30 \mathrm{~nJ} /$ pulse) that is repeated at a very high frequency (pulse duration of a few 100 femtoseconds). Inside the stroma, the tightly controlled focused laser pulse breaks down, giving rise to a series of effects, such as plasma, a shockwave, and creation of a gas $\left(\mathrm{CO}_{2}\right.$ and $\left.\mathrm{H}_{2} \mathrm{O}\right)$ cavitation bubble. ${ }^{4}$ A rasterized pattern of such successive, computer driven, tightly spaced (a few micrometers apart) cavitation bubbles forms a resection plane for a lamellar cut, enabling the separation of the overlying flap. ${ }^{5}$

\section{Flap thickness measurement in laser- assisted in situ keratomileusis (LASIK)- treated eyes}

Measurement of flap thickness in LASIK-treated eyes postoperatively is inherently challenging. In addition, measurements of thickness variability require a modality that offers not just a single-point flap thickness measurement (usually at, or close to, the cornea center), but also the simultaneous measurement of a large number of flap thicknesses over the wider corneal area affected. Most reported studies use subtraction manual intraoperative ultrasound pachymetry measurements at or near the cornea. ${ }^{6}$

There are two commercially available modalities for measuring flap thickness postoperatively for a more sophisticated and precise flap assessment: anterior-segment optical coherence tomography (AS-OCT) ${ }^{7,8}$ and arc-scanning highfrequency ultrasound biomicroscopy (HF-UBM), ${ }^{9}$ which is capable of reporting total corneal, epithelial, residual stroma, flap, and flap-stromal composition maps. ${ }^{10,11}$ Even though AS-OCT can distinguish the epithelium and flap interface, to the best of our knowledge, there is only one recently commercially available OCT system that can offer a whole-cornea epithelial map visualization. ${ }^{12}$ To the best of our knowledge, no such option exists for mapping the flap thickness of the entire corneal area by AS-OCT.

\section{Epithelial average thickness and variability following LASIK}

Postoperative epithelial thickness may be an indicator of continuing epithelial activity. Reinstein et al has introduced a new benchmark in evaluating post refractive surgery corneas by utilizing HF-UBM and evaluating the epithelial versus topographic corneal thickness distribution. ${ }^{10}$

In the case of epithelial hypertrophy, particularly if it is associated with topographic epithelial thickness irregularity, we have suggested that this may be a sign indicative of a reactive process, ${ }^{9}$ the epithelium may grow thicker in less rigid corneas that are inherently or iatrogenically weakened biomechanically and oscillate more to intraocular pressure variations and/or blinking and eye rubbing, resulting in epithelial thickening.

Precise knowledge of the epithelial central and average thickness, as well as topographic flap thickness variability over the entire cornea, may be a useful indication in the differential diagnosis of ectasia of possible myopic regression. ${ }^{13}$

\section{Purpose}

The purpose of this study was to investigate flap thickness precision and accuracy over the entire flap area affected in the form of central flap thickness as well as paracentral and peripheral topographic flap thickness variability in conjunction with epithelial thickness on LASIK flaps created by a mechanical microkeratome and two different femtosecond lasers.

\section{Patients and methods}

This retrospective interventional case series study received approval by the ethics committee of our Institution, adherent to the tenets of the Declaration of Helsinki. Informed consent was obtained from each subject prior to the surgical intervention and prior to the HF-UBM measurements.

\section{Patient inclusion and exclusion criteria}

Patients included in the study had uneventful primary LASIK for myopia by the same surgeon (AJK) between 2004 and 2010 , followed by a complication-free postoperative recovery. Treatments were between -2.00 and -10.00 diopters (D) and up to $-3.00 \mathrm{D}$ of astigmatism. None of the patients included in the study had a LASIK re-treatment. In all cases, the excimer laser ablation for the myopic correction was performed using an Allegretto Wave ${ }^{\circledR}$ Eye-Q $400 \mathrm{~Hz}$ excimer laser (WaveLight, Erlangen, Germany). ${ }^{14}$

Patients considered for the original LASIK operation were selected on the basis of no presence and/or history of: corneal dystrophy or herpetic eye disease, keratoconus (as evidenced by Placido topography and/or Scheimpflug tomography), warpage from contact lens wear, corneal scaring, glaucoma, severe dry eye, and collagen vascular diseases. 
HF-UBM corneal, flap, and epithelial thickness measurements were taken during patients' scheduled, postoperative visits ranging from 2 to 10 years postoperatively. The same examiner (GA) performed all corneal imaging and data analysis. The HF-UBM imaging was preceded by a complete ocular evaluation to screen for corneal abnormalities or postoperative complications. For example, no case with flap scarring and/or epithelial ingrowth was measured by HF-UBM.

\section{Study groups}

An equal number of left eyes (OS) and right eyes (OD) of 55 patients (ie, 110 eyes) were included in the study. Three groups were formed on the basis of original flap creation technique/instrumentation. Preoperative refractive error was similar in all groups.

Patients enrolled in Group A $(n=21$, of which seven were male and 14 female) had their flap created by the M2 microkeratome (Moria Surgical, Antony, France). ${ }^{1,2}$ The microkeratome cut was programmed to a flap thickness of $130 \mu \mathrm{m}$. Patients in Groups B and C had femtosecond laserassisted flap creation. Specifically, in Group B ( $\mathrm{n}=14$, six male, eight female), the flap was created by the IntraLase ${ }^{\mathrm{TM}}$ FS60 femtosecond laser (Abbott Medical Optics). The FS60 laser was programmed to a flap thickness of $120 \mu \mathrm{m}$ and to a flap diameter of $8.50 \mathrm{~mm}$, with a $70^{\circ}$ angled side cut and a $55^{\circ}$ hinge angle. The settings were: bed energy $0.65 \mathrm{MJ}$, side cut energy $0.8 \mathrm{MJ}$, and repetition frequency $60 \mathrm{kHz}$. Spot and line separations were, respectively, 9.0 and $9.0 \mu \mathrm{m}$ for the bed cut and 5.0 and $3.0 \mu \mathrm{m}$ for the side cut. Patients in Group C ( $n=20$, twelve male, eight female) had had their flap created by the WaveLight ${ }^{\circledR}$ FS200 femtosecond laser (Alcon, Fort Worth, TX, USA). ${ }^{15}$ The FS200 laser was programmed to a flap thickness of $120 \mu \mathrm{m}$ and to a flap diameter of $8.50 \mathrm{~mm}$, with a $70^{\circ}$ angled side cut and a $45^{\circ}$ hinge angle. The settings were: bed energy $0.90 \mathrm{MJ}$, side cut energy $0.88 \mathrm{MJ}$, and repetition frequency $200 \mathrm{kHz}$. Spot and line separations were, respectively, 8.0 and $8.0 \mu \mathrm{m}$ for the bed cut and 5.0 and $3.0 \mu \mathrm{m}$ for the side cut.

Mean postoperative time (time span from the operation to the examination) was $66.5 \pm 29.7$ months (range 33-158 months) for Group A, $52.3 \pm 14.7$ months (range 26-59 months) for Group B, and 26.7 \pm 15.3 months (range 28-44 months) for Group C.

\section{Imaging technique}

The Artemis II + superior HF-UBM system (Artemis Medical Technologies, Vancouver, BC, Canada) was employed in the study. This system produces layered corneal flap and epithelial thickness maps. ${ }^{9-11}$ Data were stored and processed using Zeus (v 1.0, build 11.780) software, licensed from Artemis Medical Technologies.

\section{Data collection and analysis}

For each eye, corneal flap and epithelial thickness measurements were obtained from the corneal report, a typical example of which is shown in Figure 1. Mean epithelial thickness overall, mean flap thickness overall (0-6 mm), central flap thickness $(0-3 \mathrm{~mm})$, and peripheral flap thickness $(3-6 \mathrm{~mm})$ were recorded from the table on the lower-left corner of the report (Figure 2). Note that thickness is referred to as "depth" in the report produced by the software.

For each eye, topographic flap and epithelial thickness variability were computed as the standard deviation of 21 different point thickness values over the entire corneal area (such as those shown in Figures 1 and 3 ). These points were spaced by $2 \mathrm{~mm}$ on the horizontal plane $\left(0^{\circ}-180^{\circ}\right.$ axis $)$ and by $1.6 \mathrm{~mm}$ on the coronal plane $\left(90^{\circ}-270^{\circ}\right.$ axis $)$.

Descriptive statistics (average, minimum, maximum, standard deviation, bias, and range), and comparative statistics were compiled and determined and linear regression performed using Microsoft Excel 2010 (Microsoft, Redmond, WA, USA) and Origin Lab (v 8; OriginLab, Northampton, MA, USA). Analysis of variance between groups was performed using the OriginLab statistics tool.

\section{Results}

Mean age, as reported at the time of LASIK operations, was $33.0 \pm 12.9$ years (range 20-56 years) for Group A, $32.6 \pm 10.7$ years (range 24-54 years) for Group B, and $29.8 \pm 12.1$ years (range 16-48 years) for Group C.

\section{Flap thickness and topographic variability}

Flap thickness measurements and statistics for the three groups (all units in micrometers $[\mu \mathrm{m}]$ ) are presented in Table 1. As shown in this table, Group A (members of which received LASIK treatment with the Moria M2) had an average postoperatively measured flap thickness of $138.83 \pm 12.38 \mu \mathrm{m}$ (average \pm standard deviation) (range 114-159 $\mu \mathrm{m}$ ). The intended (programmed) thickness was $130 \mu \mathrm{m}$. Group B (IntraLase FS60) had an average flap thickness of $128.46 \pm 5.72 \mu \mathrm{m}$ (range 119-137 $\mu \mathrm{m}$ ), with an intended (programmed) thickness of $120 \mu \mathrm{m}$. Finally, Group C (WaveLight FS200) had an average flap thickness of $122.00 \pm 5.64 \mu \mathrm{m}$ (range 94-135 $\mu \mathrm{m}$ ), 


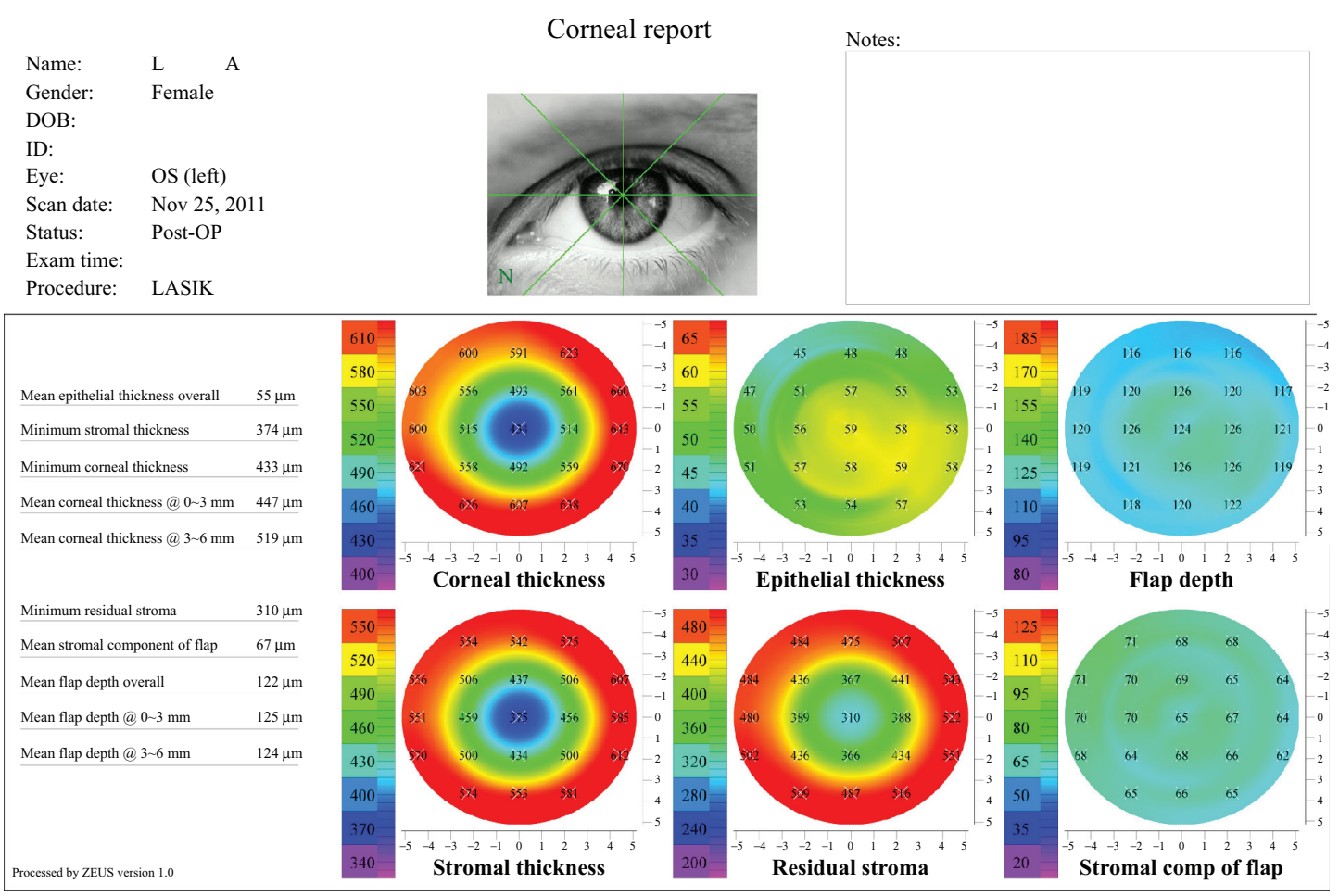

Figure I Standard corneal analysis report used in our investigation.

Note: This specific flap has been created with the FS200 femtosecond laser.

Abbreviation: LASIK, laser-assisted in situ keratomileusis.

with an intended (programmed) thickness of $120 \mu \mathrm{m}$. Representative flap thickness maps from each group are shown in Figure 3.

Column 5 in Table 1 shows the grouped topographic flap thickness values, their range, and standard deviation.

As presented in the tabulated data and illustrated in Figure 4, the mean topographic flap thickness variability was $9.73 \pm 4.93 \mu \mathrm{m}$ for Group A, $8.48 \pm 4.23 \mu \mathrm{m}$ for Group B, and $4.84 \pm 1.88 \mu \mathrm{m}$ for Group C.

Paired comparisons between the three modalities (Table 2) show that there is a statistically significant flap thickness difference between the FS200 and M2 microkeratome groups $(P=0.004)$, while the other two pairs (FS200 and FS60; FS60 and M2) were not statistically different (paired sample $t$-test, $P=0.078$ and 0.095 , respectively).

\section{Epithelial thickness and topographic variability}

To determine any potential bias in these flap thickness and/or thickness variability measurements from epithelial masking, we investigated epithelial thickness. Results per group are reported in Table 3 and illustrated in Figure 5. The mean epithelial thickness was $51.50 \pm 4.19 \mu \mathrm{m}$ in Group A, $51.54 \pm 4.16 \mu \mathrm{m}$ in Group B, and 49.53 $\pm 4.28 \mu \mathrm{m}$ in Group C.
Topographic epithelial thickness variability for the three groups was $4.15 \pm 1.53 \mu \mathrm{m}$ in Group A, $5.11 \pm 1.15 \mu \mathrm{m}$ in Group B, and $3.97 \pm 1.58 \mu \mathrm{m}$ in Group C.

In our study, none of the cases showed a significant epithelial thickness deviation that suggested early ectasia, nor did

\begin{tabular}{lc}
\hline Mean epithelial thickness overall & $55 \mu \mathrm{m}$ \\
\hline Minimum stromal thickness & $374 \mu \mathrm{m}$ \\
\hline Minimum corneal thickness & $433 \mu \mathrm{m}$ \\
\hline Mean corneal thickness @ 0 3 mm & $447 \mu \mathrm{m}$ \\
\hline & \\
\hline Mean corneal thickness @ 3 6 mm & $519 \mu \mathrm{m}$ \\
\hline
\end{tabular}

\begin{tabular}{lc} 
Minimum residual stroma & $310 \mu \mathrm{m}$ \\
\hline Mean stromal component of flap & $67 \mu \mathrm{m}$ \\
\hline Mean flap depth overall & $122 \mu \mathrm{m}$ \\
\hline Mean flap depth @ 0 3 mm & $125 \mu \mathrm{m}$ \\
\hline Mean flap depth@3 6 mm & $124 \mu \mathrm{m}$ \\
\hline
\end{tabular}

Figure 2 Detail from the lower-left table of the corneal analysis report depicted in Figure I, showing data recorded for mean epithelial thickness, mean flap depth (0-6 mm), central flap depth $(0-3 \mathrm{~mm})$, and peripheral flap depth $(3-6 \mathrm{~mm})$. 
A
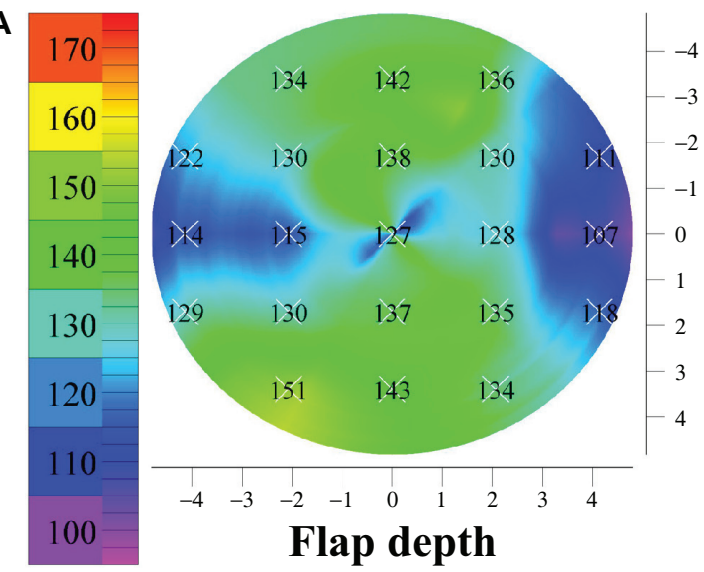

B
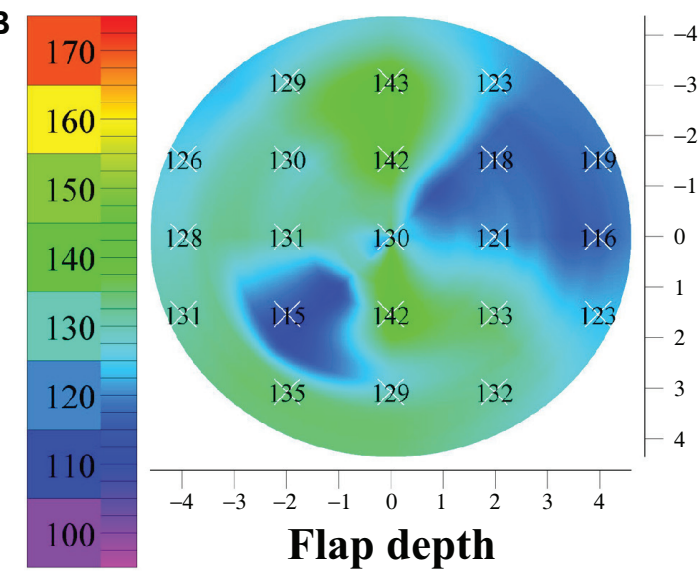

C

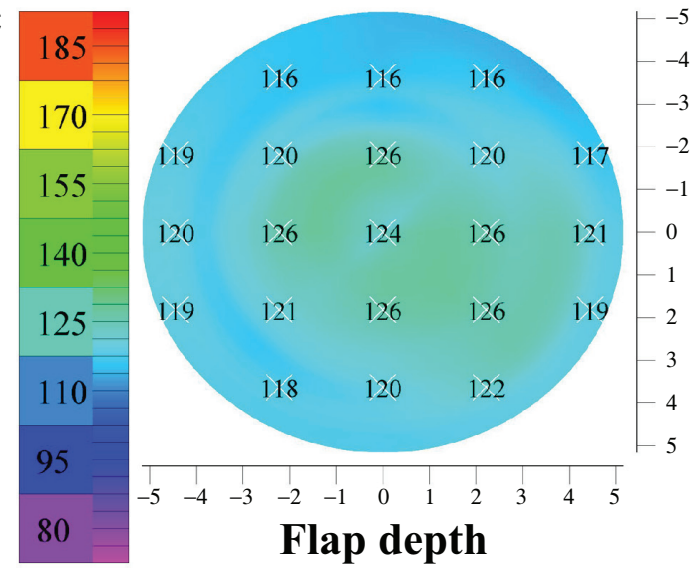

Figure 3 Three representative flap thickness maps $(8 \mathrm{~mm}$ diameter) from flaps created with the modalities studied in this paper: (A) M2 microkeratome (Moria Surgical, Antony, France), (B) Intralase ${ }^{\mathrm{TM}}$ FS60 femtosecond laser (Abbott Medical Optics, Santa Ana, CA, USA), (C) WaveLight ${ }^{\circledR}$ FS200 femtosecond laser (Alcon, Fort Worth, TX, USA).

Note: The values over the $2 I$ points are those used for the flap thickness mean and topographic flap thickness variability study.

the epithelium contribute to the flap thickness homogeneity differences found between the three groups.

\section{Discussion}

\section{The importance of flap thickness}

Flap parameter accuracy and homogeneity have been studied and debated at length by refractive surgeons globally over
Table I Flap thickness measurements, range, and topographic flap thickness variability statistics for the three groups examined

\begin{tabular}{lllll}
\hline & $\mathbf{0 - 6} \mathbf{~ m m}$ & $\mathbf{0 - 3} \mathbf{~ m m}$ & $\mathbf{3 - 6} \mathbf{~ m m}$ & $\begin{array}{l}\text { Flap thickness } \\
\text { variability }\end{array}$ \\
\hline Group A & M2 & & & \\
Average & 138.83 & 138.33 & 140.58 & 9.73 \\
Maximum & 159.00 & 159.00 & 159.00 & 17.05 \\
Minimum & 114.00 & 115.00 & 114.00 & 3.37 \\
SD & 12.38 & 12.85 & 12.09 & 4.93 \\
Group B & FS60 & & & \\
\hline Average & 128.46 & 130.31 & 128.15 & 8.48 \\
Maximum & 137.00 & 142.00 & 136.00 & 17.16 \\
Minimum & 119.00 & 120.00 & 119.00 & 2.94 \\
SD & 5.72 & 6.80 & 5.49 & 4.23 \\
Group C & FS200 & & & \\
\hline Average & 122.00 & 122.20 & 122.53 & 4.84 \\
Maximum & 135.00 & 137.00 & 136.00 & 7.96 \\
Minimum & 94.00 & 90.00 & 97.00 & 1.68 \\
SD & 5.64 & 6.11 & 5.47 & 1.88 \\
\hline N
\end{tabular}

Note: All values are expressed in micrometers $(\mu \mathrm{m})$.

Abbreviation: SD, standard deviation.

the last 10 years. There appear to be variable differences reported in the basic surgical outcomes when comparing procedures with flaps created either with a mechanical microkeratome or a femtosecond laser. ${ }^{16}$ For example, a study in hyperopic patients showed significantly better refractive results with femtosecond laser flaps than with microkeratome flaps. ${ }^{17}$ Another study showed that clinically significant epithelial ingrowth after femtosecond LASIK is an infrequent complication, the incidence being less than reported for microkeratome LASIK. ${ }^{18}$

Despite the fact that multiple generations of femtosecond lasers for refractive surgery have been introduced so far, and while the "perfect LASIK flap" is becoming increasingly tangible, the field continues to welcome research on the comparative characteristics of the femtosecond laser versus mechanical microkeratome flap, including that on morphology, cut accuracy, flap thickness reproducibility, flap-edge quality, stromal-bed surface roughness, and histopathology. ${ }^{19-25}$

The femtosecond laser continues to be preferred for flap creation over the bladed mechanical microkeratome due to the increased safety, precision, and regularity this modality offers. ${ }^{26,27}$

Flap thickness is considered an important indicator of LASIK safety due to the critical importance of adequate residual stromal preservation, not only at the center of the cornea, but also for the overall area of the cornea affected. To ensure a thicker residual stroma, a thin flap is preferable in myopic treatments. A further benefit of a thin flap (in 


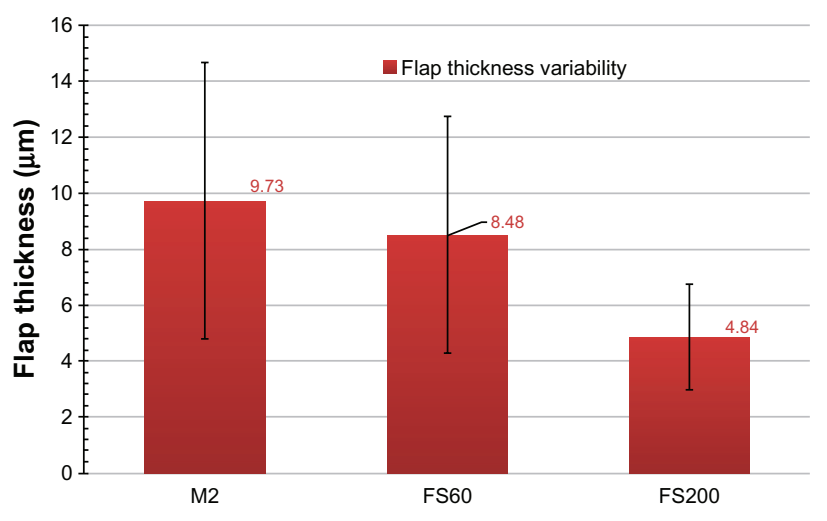

Figure 4 Postoperative topographic flap thickness variability for the three groups examined.

Notes: "FS60" refers to the IntraLase TM FS60 femtosecond laser manufactured by Abbott Medical Optics, Santa Ana, CA, USA; "FS200" refers to the WaveLight ${ }^{\circledR}$ FS200 femtosecond laser manufactured by Alcon, Fort Worth, TX, USA; "M2" refers to the $\mathrm{M} 2$ microkeratome manufactured by Moria Surgical, Antony, France.

addition to a smaller diameter) is reduced interference of the superficial "running" nerves within the corneal stroma, which can lessen postoperative dry-eye syndrome. ${ }^{28}$ However, the risk in opting for a thin flap is that the flap may end up too thin - that is, a flap $<90 \mu \mathrm{m}$. Such a flap may be associated with flap slippage, striae, irregularity, astigmatism, buttonholes, free caps, and corneal haze. ${ }^{29,30}$

However, thicker flaps (for myopic treatment, a flap $>140 \mu \mathrm{m}$ is acknowledged as being too thick) may lead to a dangerously thin residual stroma (after the excimer ablation), possibly compromising the biomechanical corneal strength and leading to iatrogenic corneal ectasia. ${ }^{31}$

However, the $140 \mu \mathrm{m}$ flap has been considered by our team optimal for hyperopic ablation and its accompanying (large-diameter) blend zone, as a means to reduce epithelial ingrowth. ${ }^{14}$

Thus, to ensure safety of the procedure and enable borderline decisions to be made - such as in operations with relatively thin residual stroma - it is of ultimate importance that both a higher precision (intended vs achieved thickness) and increased accuracy (improved homogeneity, or else reduced thickness variability) of the lamellar flap cut or stromal tissue separation be sought when selecting a femtosecond laser.

Table 2 Paired sample $t$-tests $(P)$ between the three pairs of flapcreation modalities examined

\begin{tabular}{llll}
\hline & $\begin{array}{l}\text { FS200 and } \\
\text { microkeratome }\end{array}$ & $\begin{array}{l}\text { FS200 and } \\
\text { FS60 }\end{array}$ & $\begin{array}{l}\text { FS60 and } \\
\text { microkeratome }\end{array}$ \\
\hline $\begin{array}{l}\text { Flap thickness } \\
\text { Epithelial }\end{array}$ & 0.004 & 0.078 & 0.095 \\
thickness & 0.020 & 0.056 & 0.084 \\
\hline
\end{tabular}

Table 3 Epithelial thickness measurements and statistics for the three groups examined

\begin{tabular}{lll}
\hline & $\begin{array}{l}\text { Average overall } \\
\text { epithelial thickness }\end{array}$ & $\begin{array}{l}\text { Topographic epithelial } \\
\text { thickness variability }\end{array}$ \\
\hline Group A & M2 & \\
Average & 51.50 & 4.15 \\
Maximum & 57.00 & 7.51 \\
Minimum & 43.00 & 1.28 \\
SD & 4.19 & 1.53 \\
Group B & FS60 & \\
\hline Average & 51.54 & 5.11 \\
Maximum & 58.00 & 6.92 \\
Minimum & 44.00 & 3.42 \\
SD & 4.16 & 1.15 \\
Group C & FS200 & \\
\hline Average & 49.53 & 3.97 \\
Maximum & 56.00 & 7.56 \\
Minimum & 42.00 & 1.10 \\
SD & 4.28 & 1.58 \\
\hline
\end{tabular}

Note: All values are expressed in micrometers $(\mu \mathrm{m})$.

Abbreviation: SD, standard deviation.

Our results indicate that the postoperative flap thickness, as measured by the HF-UBM method, is larger than the programmed flap thickness and that there are differences between the peripheral and the central thickness. In Group A, overall flap thickness was thicker than planned by $+8.83 \mu \mathrm{m}$ (minimum, $114 \mu \mathrm{m}-$ ie, a $-6 \mu \mathrm{m}$ average difference; maximum, $159 \mu \mathrm{m}$ - ie, a $+39 \mu \mathrm{m}$ difference) with an average thickness standard deviation of $12.38 \mu \mathrm{m}$. In addition, we observe that this group had the largest topographic thickness variability $(9.73 \pm 4.93 \mu \mathrm{m})$, which is an indication of the inhomogeneity of the flap thickness produced by the microkeratome. We also observe that in this group, on average, the flaps were thicker in the periphery (average $140.58 \mu \mathrm{m}$ in the $3-6 \mathrm{~mm}$ zone vs an average of $138.33 \mu \mathrm{m}$ in the central $0-3 \mathrm{~mm}$ zone), owing to the socalled meniscus shape. ${ }^{23}$

In Group B, we also observe that the overall flap thickness was thicker than planned, by $+8.46 \mu \mathrm{m}$. However, the range is smaller (minimum, $119 \mu \mathrm{m}$, maximum, $137 \mu \mathrm{m})$, and so is the standard deviation $(6.80 \mu \mathrm{m})$. The flap thickness variability is smaller than that of Group A $(8.48 \pm 4.23 \mu \mathrm{m})$. In Group B, we observe that, on average, the flaps were thinner in the peripheral zone (average peripheral thickness, $128.15 \mu \mathrm{m}$ ) compared with in the central zone (average central thickness, $130.31 \mu \mathrm{m})$.

In Group $\mathrm{C}$, we observe that the average postoperative flap thickness was just $2.00 \mu \mathrm{m}$ thicker than programmed and that flaps in this group had the smallest topographic 


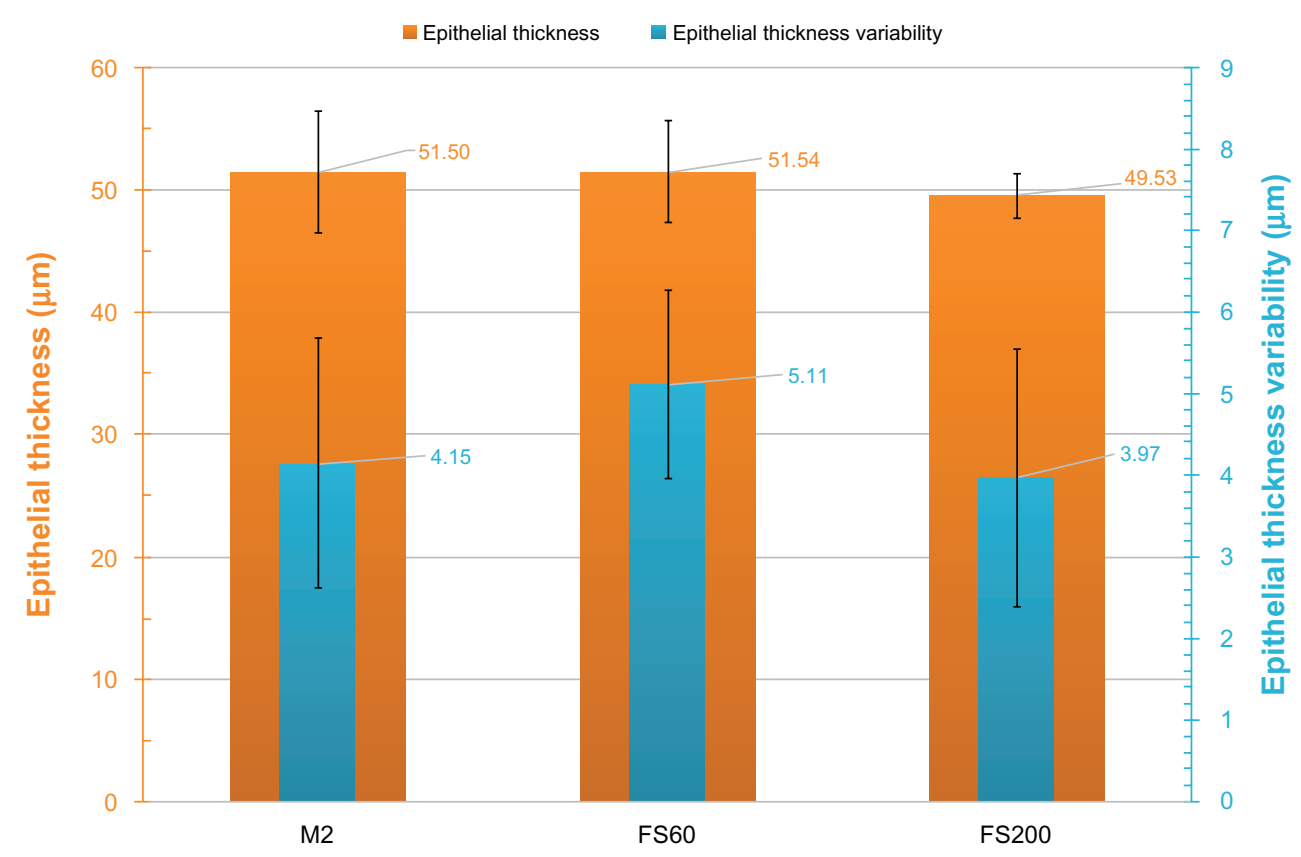

Figure 5 Postoperative epithelial thickness and topographic epithelial thickness variability for the three groups examined.

Notes: "FS60" refers to the Intralase ${ }^{\mathrm{TM}}$ FS60 femtosecond laser manufactured by Abbott Medical Optics, Santa Ana, CA, USA; "FS200" refers to the WaveLight ${ }^{\circledR}$ FS200 femtosecond laser manufactured by Alcon, Fort Worth, TX, USA; "M2" refers to the M2 microkeratome manufactured by Moria Surgical, Antony, France.

thickness variability $(4.84 \mu \mathrm{m} \pm 1.88 \mu \mathrm{m})$. This group also had nonstatistically different peripheral and central flap thicknesses (central flap thickness, $122.20 \pm 6.11$; peripheral flap thickness, $122.53 \pm 6.11 \mu \mathrm{m})$.

It is worth comparing our results to a similar recent study, ${ }^{32}$ in which a handheld AS-OCT unit was used to measure postoperative flap thickness. In that study, the standard deviation for paracentral flap thickness and peripheral flap thickness was reported to be $\pm 3.16 \mu \mathrm{m}$ and $\pm 3.26 \mu \mathrm{m}$, respectively, for the FS200 group and $\pm 10.27 \mu \mathrm{m}$ and $\pm 10.35 \mu \mathrm{m}$ for the Hansatome microkeratome, respectively.

\section{Differences between the two femtosecond lasers in terms of flap thickness variability}

An interesting finding of our study is that the measured topographic flap thickness variability was smaller for the FS200 group than for the FS60 and M2 microkeratome groups. The FS200 flaps appeared to be more uniform, with an average topographic thickness variability of $4.84 \pm 1.88 \mu \mathrm{m}$, whereas this was $8.48 \pm 4.23 \mu \mathrm{m}$ for the FS60 group and $9.73 \pm 4.93 \mu \mathrm{m}$ for the M2 microkeratome group.

In addition, the FS200 flaps were associated with a statistically significant smaller epithelial average thickness $(49.53 \pm 4.28 \mu \mathrm{m}$, range $42-56 \mu \mathrm{m})$ over the other groups: the FS60 group had an average epithelial thickness of $51.54 \pm 4.16 \mu \mathrm{m}$ (range 44-58 $\mu \mathrm{m}$ ) and the microkeratome group had an average epithelial thickness of $51.50 \pm 4.19 \mu \mathrm{m}$ (range 43-57 $\mu \mathrm{m}$ ). The FS60 and M2 microkeratome were not statistically different in terms of epithelial thickness variability.

The difference between the flap thickness variability of the FS200 and the FS60 may stem from their different intraoperative gas-venting techniques and/or their different - active versus passive - intraoperative suction methods. Intraoperative gas buildup during creation of the lamellar part of the flap (opaque bubble layer) ${ }^{33}$ may interfere with the precision of the femtosecond laser tissue separation. In contrast, variation in the stabilizing force to the cornea during this process, through the applanation pressure applied, may also result in tissue separation bias. The FS60 uses a passive syringe chamber-induced suction that is achieved prior to cornea applanation and maintained passively during the procedure, while the FS200 uses a tubing system that connects the suction ring to an active vacuum pump within the unit that monitors and maintains stable suction during the lamellar cut procedure.

The first step in creating the flap is the creation of an externalizing channel peripheral to the hinge of the flap, permitting the generated gas to diffuse outside of the cornea. The different initial steps in creating femtosecond laser-assisted flaps are illustrated in Figure $6-$ the channel 

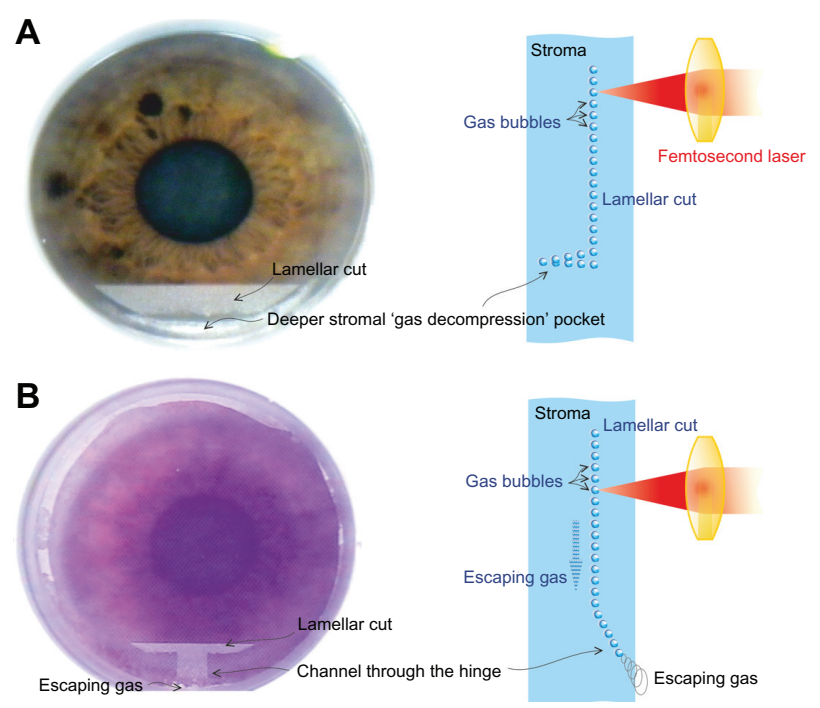

Figure 6 Schematic of the architectural differences between the (A) Intralase ${ }^{T M}$ FS60 (Abbott Medical Optics, Santa Ana, CA, USA) and (B) WaveLight ${ }^{\circledR}$ FS200 (Alcon, Fort Worth, TX, USA) femtosecond lasers.

Notes: In the initial phase of flap creation with the FS60, a stromal "gas decompression" pocket is created, while, with the FS200, a channel through the hinge is created to help the gas escape.

is clearly shown in 6B (FS200), whereas there is no such channel in 6A (FS60).

We conclude that all three devices are very safe and offer great efficacy in flap making. Both femtosecond lasers appear to be more accurate in generating the desired central corneal flap thickness, as expected. However, the dramatic difference in overall flap thickness between the FS200 and the other two modalities studied herein may suggest that the FS200 has a better aberrations profile and better mesopic and scotopic visual functions. As our momentum in corneal imaging expands, we may come to explain and understand visual function parameters beyond acuity and refraction that may be significant in assessing modern refractive surgery.

\section{Conclusion}

Our study suggests that the WaveLight FS200 femtosecond laser has a statistically higher precision in planar flap thickness creation as flaps created with this laser have a statistically smaller flap thickness area variation when compared with the flaps produced by the IntraLase FS60 and M2 microkeratome. The difference between the FS200 and the FS60 may stem from their different intraoperative gas-venting techniques and/or their different - active versus passive - intraoperative suction methods.

\section{Disclosure}

AJK consults for Alcon. The authors declare no other conflicts of interest in this work.

\section{References}

1. Kanellopoulos AJ, Pe LH, Kleiman L. Moria M2 single use microkeratome head in 100 consecutive LASIK procedures. J Refract Surg. 2005;21(5):476-479.

2. Kanellopoulos AJ, Conway J, Pe LH. LASIK for hyperopia with the WaveLight excimer laser. J Refract Surg. 2006;22(1):43-47.

3. Reggiani-Mello G, Krueger RR. Comparison of commercially available femtosecond lasers in refractive surgery. Expert Rev Opthalmol. 2011;6(1):55-56.

4. Juhasz T, Kastis GA, Suárez C, Bor Z, Bron WE. Time-resolved observations of shock waves and cavitation bubbles generated by femtosecond laser pulses in corneal tissue and water. Lasers Surg Med. 1996;19(1):23-31.

5. Salomão MQ, Wilson SE. Femtosecond laser in laser in situ keratomileusis. J Cataract Refract Surg. 2010;36(6):1024-1032.

6. Murakami Y, Manche EE. Comparison of intraoperative subtraction pachymetry and postoperative anterior segment optical coherence tomography of laser in situ keratomileusis flaps. J Cataract Refract Surg. 2011;37(10):1879-1883.

7. von Jagow B, Kohnen T. Corneal architecture of femtosecond laser and microkeratome flaps imaged by anterior segment optical coherence tomography. J Cataract Refract Surg. 2009;35(1):35-41.

8. Xu Y, Zhou X, Wang L, Xu H. A morphological study of corneal flap after thin-flap laser-assisted in situ keratomileusis by anterior segment optical coherence tomography. J Int Med Res. 2010;38(6):1952-1960.

9. Kanellopoulos AJ, Aslanides IM, Asimellis G. Correlation between epithelial thickness in normal corneas, untreated ectatic corneas, and ectatic corneas previously treated with CXL; is overall epithelial thickness a very early ectasia prognostic factor? Clin Ophthalmol. 2012;6:789-800.

10. Reinstein DZ, Silverman RH, Raevsky T, et al. Arc-scanning very high-frequency digital ultrasound for 3D pachymetric mapping of the corneal epithelium and stroma in laser in situ keratomileusis. J Refract Surg. 2000;16(4):414-430.

11. Reinstein DZ, Archer TJ, Gobbe M. LASIK flap thickness profile and reproducibility of the standard vs zero compression Hansatome microkeratomes: three-dimensional display with Artemis VHF digital ultrasound. J Refract Surg. 2011;27(6):417-426.

12. Kanellopoulos AJ, Asimellis G. Anterior segment optical coherence tomography - assisted topographic corneal epithelial thickness distribution imaging of a keratoconus patient. Case Rep Ophthalmol. DOI: 10.1159/000350630. In press.

13. Spadea L, Fasciani R, Necozione S, Balestrazzi E. Role of the corneal epithelium in refractive changes following laser in situ keratomileusis for high myopia. J Refract Surg. 2000;16(2):133-139.

14. Kanellopoulos AJ. Topography-guided hyperopic and hyperopic astigmatism femtosecond laser-assisted LASIK: long-term experience with the $400 \mathrm{~Hz}$ eye-Q excimer platform. Clin Ophthalmol. 2012;6:895-901.

15. Mrochen M, Wüllner C, Krause J, Klafke M, Donitzky C, Seiler T. Technical aspects of the WaveLight FS200 femtosecond laser. J Refract Surg. 2010;26(10):S833-S840.

16. Zhang ZH, Jin HY, Suo Y, et al. Femtosecond laser versus mechanical microkeratome laser in situ keratomileusis for myopia: Metaanalysis of randomized controlled trials. J Cataract Refract Surg. 2011; 37(12):2151-2159.

17. Gil-Cazorla R, Teus MA, de Benito-Llopis L, Mikropoulos DG. Femtosecond laser vs mechanical microkeratome for hyperopic laser in situ keratomileusis. Am J Ophthalmol. 2011;152(1):16-21.

18. Kamburoğlu G, Ertan A. Epithelial ingrowth after femtosecond laserassisted in situ keratomileusis. Cornea. 2008;27(10):1122-1125.

19. Kezirian GM, Stonecipher KG. Comparison of the IntraLase femtosecond laser and mechanical keratomes for laser in situ keratomileusis. J Cataract Refract Surg. 2004;30(4):804-811.

20. Holzer MP, Rabsilber TM, Auffarth GU. Femtosecond laser-assisted corneal flap cuts: morphology, accuracy, and histopathology. Invest Ophthalmol Vis Sci. 2006;47(7):2828-2831.

21. Kim JY, Kim MJ, Kim TI, Choi HJ, Pak JH, Tchah H. A femtosecond laser creates a stronger flap than a mechanical microkeratome. Invest Ophthalmol Vis Sci. 2006;47(2):599-604. 
22. Montes-Micó R, Rodríguez-Galietero A, Alió JL. Femtosecond laser versus mechanical keratome LASIK for myopia. Ophthalmology. 2007;114(1):62-68.

23. Ahn H, Kim JK, Kim CK, et al. Comparison of laser in situ keratomileusis flaps created by 3 femtosecond lasers and a microkeratome. J Cataract Refract Surg. 2011;37(2):349-357.

24. Chen S, Feng Y, Stojanovic A, Jankov MR 2nd, Wang Q. IntraLase femtosecond laser vs mechanical microkeratomes in LASIK for myopia: a systematic review and meta-analysis. J Refract Surg. 2012; 28(1):15-24.

25. Khoramnia R, Salgado JP, Lohmann CP, Kobuch KA, von Mohrenfels CW. Precision, morphology, and histology of corneal flap cuts using a 200-kHz femtosecond laser. Eur J Ophthalmol. 2012; 22(2):161-167.

26. Kohnen T, Klaproth OK, Derhartunian V, Kook D. [Results of 308 consecutive femtosecond laser cuts for LASIK.] Ophthalmologe. 2010;107(5):439-445. [German].

27. Heichel J, Hammer T, Sietmann R, Duncker GI, Wilhelm F. [Scanning electron microscopic characteristics of lamellar keratotomies using the Femtec femtosecond laser and the Zyoptix XP microkeratome. A comparison of quality.] Ophthalmologe. 2009;107(4):333-340. [German].
28. Kanellopoulos AJ, Pallikaris IG, Donnenfeld ED, Detorakis S, Koufala K, Perry HD. Comparison of corneal sensation following photorefractive keratectomy and laser in situ keratomileusis. J Cataract Refract Surg. 1997;23(1):34-38.

29. Choudhri SA, Feigenbaum SK, Pepose JS. Factors predictive of LASIK flap thickness with the Hansatome zero compression microkeratome. $J$ Refract Surg. 2005;21(3):253-259.

30. Hatch BB, Moshirfar M, Ollerton AJ, Sikder S, Mifflin MD. A prospective, contralateral comparison of photorefractive keratectomy (PRK) versus thin-flap LASIK: assessment of visual function. Clin Ophthalmol. 2011;5:451-457.

31. Koch DD. The riddle of iatrogenic keratectasia. J Cataract Refract Surg. 1999;25(4):453-454.

32. Shetty R, Malhotra C, D'Souza S, Wadia K. WaveLight FS200 vs Hansatome LASIK: Intraoperative Determination of Flap Characteristics and Predictability by Hand-held Bioptigen Spectral Domain Ophthalmic Imaging System. J Refract Surg. 2012;28(11):S815-S820.

33. Kanellopoulos AJ, Asimellis G. Digital analysis of flap parameter accuracy and objective assessment of opaque bubble layer in femtosecond laser-assisted LASIK: a novel technique. Clin Ophthalmol. 2013;7:1-9.
Clinical Ophthalmology

\section{Publish your work in this journal}

Clinical Ophthalmology is an international, peer-reviewed journal covering all subspecialties within ophthalmology. Key topics include: Optometry; Visual science; Pharmacology and drug therapy in eye diseases; Basic Sciences; Primary and Secondary eye care; Patient Safety and Quality of Care Improvements. This journal is indexed on

Submit your manuscript here: http://www.dovepress.com/clinical-ophthalmology-journal

\section{Dovepress}

PubMed Central and CAS, and is the official journal of The Society of Clinical Ophthalmology (SCO). The manuscript management system is completely online and includes a very quick and fair peer-review system, which is all easy to use. Visit http://www.dovepress.com/ testimonials.php to read real quotes from published authors. 